CHAPTER 9

\title{
Grand Aspirations: Putting Pip on the Stage Adaptations and Absences
}

\author{
Michael Eaton
}

Writing to his friend John Forster in 1837 of theatrical performances of his works, specifically an early pirated version of The Pickwick Papers, Dickens observed:

Well; if the Pickwick has been the means of putting a few shillings in the vermin-eaten pockets of so miserable a creature, and has saved him from a workhouse or a jail, let him empty out his little pot of filth and welcome. I am quite content to have been the means of relieving him. (Letters 1:304)

This gives some indication of his understandable attitude to the 'purloiners' of his work; on another occasion, he attended a performance of a play of Oliver Twist and 'laid himself down upon the floor in a corner of the box and never rose from it until the drop-scene fell' (Forster 381). I suppose I must include myself among this number. Nevertheless, this chapter offers reflections on my adaptation of Great Expectations for the West Yorkshire Playhouse in March/ April 2016 (directed by Lucy Bailey), exploring the decisions made in adapting Great Expectations for a new theatrical production and demonstrating how the

\section{How to cite this book chapter:}

Eaton, M. 2020. Grand Aspirations: Putting Pip on the Stage Adaptations and Absences. In: Bell, E. (ed.), Dickens After Dickens, pp. 177-195. York: White Rose University Press. DOI: https://doi.org/10.22599/DickensAfterDickens.j. Licence, apart from specified exceptions: CC BY-NC 4.0 
constraints and opportunities of the medium determine dramaturgical choices. I shall also explore efforts to put Pip on the stage from the late 19th century to the present, considering the role of illustration in visualising the novel and the text's chequered performance history.

\section{What should Great Expectations look like?}

Unlike readers of his earlier serialised works, those who followed the instalments of Great Expectations in the pages of All The Year Round from December 1860 to August 1861 were given no visual representations of the characters, situations, and setting (in fact, of all of Dickens's novels, only Great Expectations and Hard Times were first published without any illustrations). There was no help from a 'Phiz' or even from a John Leech. It was across the Atlantic that the work was first illustrated, by John McLenan in the serialisation by Harper's Weekly: A Journal of Civilization, which actually went on sale one week ahead of the British publication. Though this artist was known as 'the American Phiz', I doubt anyone would claim his 40 pictures to be the equal of the work of Hablot K. Browne (whose illustrations are briefly discussed by Katie Bell in Chapter 3). Nevertheless, transatlantic readers were treated to a fuller aesthetic experience than those who consumed the new story in the austere, unillustrated, small print of the weekly conducted by the Inimitable himself. ${ }^{1}$

Back home, readers would have to wait a year until the tale was eventually published in the one-volume Chapman and Hall Library Edition, containing a measly eight woodcuts by Marcus Stone. Stone, only 22 years old, was the son of Dickens's late friend and neighbour, Frank Stone, and Dickens had rather taken him under his wing and into the bosom of the family. Critics such as Malcolm Andrews have argued that Dickens had been disappointed with Phiz's pictures for A Tale of Two Cities when it was reissued in monthly parts, and was after a much more 'realistic' (Schelstraete 55) depiction, in line with the fashion of the 1860s. ${ }^{2}$ Great Expectations has comparatively few comic scenes, though is far from devoid of great dramatis personae drawn with a characteristically Dickensian broad brush. Whatever the disputed circumstances of Stone's advancement, I am not alone in finding his pictures entirely lifeless, not succeeding at what Emily Eells describes as a 'freezing of the action' in her discussion of McLenan's illustrations (220). ${ }^{3}$ (Although Stone undoubtedly quitted himself far more creditably, taking on Our Mutual Friend, when Dickens reverted to monthly publication.)

Other illustrators followed throughout the 19th century: most notably, in America, Sol Eytinge Junior, who was commissioned for the Diamond Edition knocked out to cash in on Dickens's reading tour of 1867-68, and, in England, Frederick Pailthorpe for an 1885 edition. None of these provides particularly memorable additions to the Charles Dickens Picture Book, and none of these 


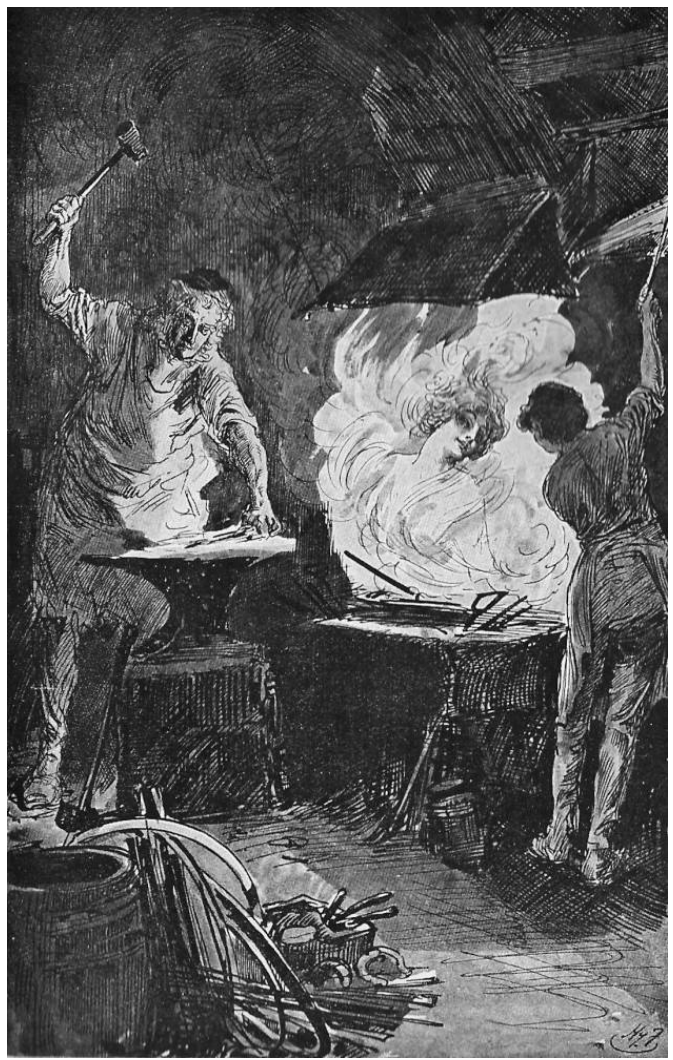

Figure 9.1: Pip fancies he sees Estella's Face in the Fire, lithograph by Harry Furniss, 1910. Source: Victorian Web http://www.victorianweb.org/art/illustration/furniss/front.html. Scanned image by Philip V. Allingham.

artists come close to capturing either the melancholic profundity or the (occasional) bizarre comicality of this masterpiece of thwarted, deluded aspirations. Cumulatively, though, they all combine to give some visual embodiment to a story originally conceived without pictures. But at the end of the 19th century Pip, Joe, Miss Havisham, Estella, Wopsle, Wemmick, Jaggers, et al. remained definitively undrawn.

My own visual introduction to Great Expectations came through the Classics Illustrated comic, with its striking cover of the opening chapter. But I was very fortunate to read the work itself for the first time in the 1910 Charles Dickens Library edition, which I inherited from my grandfather. This contained 27 drawings by the great and prolific Harry Furniss (also a cinematic pioneer), ${ }^{4}$ who was proud of his reputation as the first illustrator of the entire Dickens canon. At last, Great Expectations had pictures worthy of the prose. 


\section{A drama on many stages}

Dickens may be the Inimitable, but he is far from the Unadaptable. From the first rise of his celebrity, his stories and characters had a life outside his own management, and to no pecuniary advantage to himself. His reaction, in this age before widespread copyright, was understandably forthright, both here and, especially, in America. ${ }^{5}$

This bare-faced larceny was particularly acute in the theatrical versions, staged often before the books themselves had completed their serialisation. Dickens puts his own complaints into the mouth of the eponymous hero of Nicholas Nickleby (1838):

[Y]ou drag within the magic circle of your dulness, subjects not at all adapted to the purposes of the stage ... you take the uncompleted books of living authors, fresh from their hands, wet from the press, cut, hack, and carve them ... hastily and crudely vamp up ideas not yet worked out by their original projector, do your utmost to anticipate his plot - all this without his permission, and against his will; ... to which you put your name as author ... Now, show me the difference between such pilfering as this, and picking a man's pocket in the street... . (633)

A decade into his literary career, however, Dickens got wise and found a way to be to be in control of his own work. For his third Christmas Book, The Cricket on the Hearth (1845), Dickens did a financial deal with the Lyceum Theatre, run by a far more celebrated theatrical family than the Crummles: the Keeleys. The correspondent of The Almanack of the Month, 'W.H.W., explained:

That the Cricket might be served up quite warm to the play going public, on the foyer of the Lyceum Theatre, its author - Mr. Charles Dickens - supplied the dramatist, Mr. Albert Smith, with proof-sheets hot from the press. On the evening of the morning, therefore, on which the book was published, its dramatic version was produced; and, as the adaptor stuck very closely indeed to the text of the original, of course it succeeded. (quoted in Edgar Pemberton 158)

This 'authorised version' pipped the first competitor to the post by 11 days. By the time Smith's play opened in New York on 21 February 1846, there had already been no fewer than 21 other productions mounted in Britain!

The same dodge was attempted in 1861 with the publication, at the office of All The Year Round on Wellington Street, Strand, of Great Expectations: A Drama in Three Stages. Founded on, and Compiled from, the Story of That Name, the title page clearly declaring it to be 'By Charles Dickens'. Malcolm Morley, who wrote an invaluable series of articles chronicling theatrical adaptations in 
the Dickensian throughout the mid-1950s, considers this to be an attempt to 'retain stage copyright', to secure 'protection from pilfering bookwrights' (79). Though issued under Dickens's own name, Morley speculates that it was quite probably arranged by someone else in the All The Year Round office. There is no evidence to suggest this dramatisation was ever produced, and copies are extremely rare. ${ }^{6}$ Philip V. Allingham, in an article on the Victorian Web, gives a précis of this, quoting Worth:

There is no chase, no capture, no trial, no deathbed scene for Magwitch; more important, there is no remorse, no repentance, no reformation for Pip. (172)

Allingham reproduces the title page and the cast of characters, also rationally speculating that the omission of actors' names against the dramatis personae 'suggest(s) that the play was never performed' ('Who wrote the 1861 adaptation of Great Expectations?'). In this list, that there is no (a word which will recur throughout) Wopsle, no Wemmick, so no Aged P, no Trabb nor his boy, no Bentley Drummle, though Orlick is there, as are the insignificant Sarah, Georgiana, and Camilla Pocket, billed as Miss Havisham's relations.

But there is one adaptation which, though again never destined to be performed, was certainly produced by Dickens's own hand in an attempt to gain complete control over his own work - for financial exploitation as well as great enjoyment.

For three years after he gave the first paid reading of one of his works - an (almost) complete rendition of A Christmas Carol - he himself rendered the recently finished book into a version to be delivered on his public reading tours. ${ }^{7}$ Strangely, rather than selecting a particular section of the entire story (as he did with, for instance, The Pickwick Papers, Martin Chuzzlewit, Dombey and Son and David Copperfield), Dickens attempted to digest the entire novel. The resulting text ran to 160 printed pages and 30,000 words, which, had it ever been delivered, would have lasted over three hours. Such an abridgement necessarily led to conflations and excisions, some more surprising than others. In making the story of Pip and Magwitch the main spine, there was no Orlick and no Biddy but, amazingly, also no Estella. As subsequent adapters were to follow, myself included, the early visits to Satis House were conflated into one scene, as were the scenes after Magwitch's return when Pip learns the backstory of his unexpected and unwelcome benefactor. Among some of the most comical, yet thematically significant, moments to be left on the cutting room floor, there was no visit of Joe to London. This gloriously embarrassing chapter might have made a delightful reading on its own, as would Wemmick escorting Pip to the Walworth 'castle' to meet the Aged P, or Wopsle playing the title role in Hamlet.

By far the greatest challenge to any adaptation in whatsoever medium is how to convey the growing awareness of the older Pip, the first-person narrator, 
upon his boyhood experiences in the marshes and the self-serving actions of his life as a young man in London, before the revelation of the tainted source of his expectations. Small wonder Dickens abandoned the idea of giving this revised version of the entire work. Did he soon come to realise that his profundity would perforce be lost in this cut-down version for public performance? Should Estella be ejected from Pip's Bildungsroman, the central theme of the vast abyss separating the classes and the deluded quest of the 'hero' to become a 'gentleman' worthy of such a lady (of whose own even more low-born origins he is entirely unaware) could never be represented.

Callaghan concludes:

[T] he reading version turns the novel into little more than a heartwarming morality tale, Victorian in its emphasis on the value of hard work and selflessness and the crossing of social boundaries through sympathy, but largely independent of a specific social and economic milieu. (555)

Perhaps there is something about this masterpiece which makes it inimical to transposition into any dramatic medium? Perhaps its perfect existence should best remain in the relationship between the writer's words on the page and the mind of the reader avidly consuming them, eschewing illustration and adaptation? But fools continue to rush in...

Malcolm Morley writes of several American productions throughout the $1860 \mathrm{~s}$, for one of which 'the price of admission included the sight of a living hippopotamus in the Museum to which the theatre had been grafted by the big time showman Phineas T. Barnum' (Morley 80). Londoners would have to wait until after Dickens's death, on 9 June 1870, for a theatrical version, which opened at the Court Theatre almost a year later in May 1871. This adaptation was the work of a barrister and, at that time, amateur playwright, W. S. Gilbert. In a letter to The Times, the soon-to-be Savoyard claimed, 'Before I commenced to adapt Great Expectations I applied for, and obtained, the express permission of Mr. Charles Dickens, jun (9)'.

Philip H. Bolton, in his monumental catalogue Dickens Dramatized (1987), records that the show crossed the Atlantic to play Boston and was revived in London six years later, so it must be counted as something of a success.

Gilbert deals with the long chronology of the original by having a prologue on the marshes preceding three acts. As was common in those days, both Pips, 'a child of seven' (1) and the older incarnation when 'ten years have elapsed' (9), were played by female actors (Jennie Lee, for instance, forged a career from her personation of 'Little Jo the Crossing Sweeper' from Bleak House.) The prologue follows the early chapters quite faithfully, with one significant change: the threatened 'Young Man' is here not Compeyson but 'another escaped convict' (5) - Dolge Orlick - who will become the villain of the piece. This tilts the piece 
from the off towards conventional melodrama, erasing Magwitch's class resentment against the exploitative 'gentleman'.

If Dickens had made a surprising excision in his reading version by getting rid of Estella, Gilbert contrives an even more brutal erasure. For, though spoken of, there is no appearance of Miss Havisham. Also referred to but never allowed to don the motley is poor Wopsle. Joe is given his fair due, as is Jaggers. But the most outstanding modification to the fundamental storyline occurs at the end of Act III - which only goes to show that everyone, even Dickens himself, has trouble providing satisfying 'closure' to this troubling story.

The climax takes place at the sluice house, where Orlick is about to throttle Pip. There are those commentators who have seen Orlick as Pip's evil twin, a Jungian shadow - a critical concept which, I must admit, I have never quite bought. ${ }^{9}$ But Gilbert may well have anticipated this interpretation. Magwitch enters in the nick of time to dispatch the antagonist before Joe, Herbert, Estella, and Biddy appear on the scene. Old Provis is then shot by a police sergeant. Before he draws his final breath, Pip reveals to him that Estella is his daughter though how Pip himself knows this amazing news is something of a mystery - and that she will be his wife. The stage direction reads '(Magwitch makes a violent effort to embrace Estella. He kisses her, places her hand in Pip's, and dies)' (50). The sensational demands of 19th-century popular theatre are thus satisfied entirely at the expense of the psychological anxieties of the original.

The Times of 2 June 1871 was complimentary, praising Gilbert for performing 'a task by no means easy with considerable skill', though it is perceptive about the role of Pip: 'it may be laid down as a general truth that the so-called "hero" of a narrative fiction, the person whose adventures constitute its substance, and who is always in the presence of the reader, never asserts his importance on the stage. It concludes with some sadness, 'we cannot forebear the remark that no dramatic version, however skilful or complete, can convey even a faint notion of the work of our great and lamented novelist'. When the show was revived at the Royal Westminster Aquarium (don't ask - I didn't) in March 1877 , the notice in the 'Thunderer' was less effusive. Gilbert, usually so 'ingenious' an adapter, was said to have produced 'a somewhat dull play ... a failure'. The reviewer regrets the absence of Miss Haversham (sic) - a name destined to be misspelled as frequently as that of Bill Sikes, whose ' $i$ ' is so often substituted with a ' $y$ '. A general reflection on dramatic adaptation is well made:

A knowledge of the novel would certainly render the play intelligible, but in adaptations of the best-known works of fiction such knowledge should never be presumed. If a play can only be understood by reference to what is not presented on the stage, if the action which is exhibited on the stage is only intelligible by a knowledge of the action which occurs off the stage, it is obvious that this play must be deficient in one of the first qualifications for dramatic success. 
And yet still we persist...

Passing over other, relatively few, dramatisations, there is one worthy of mention, for reasons that will become apparent. This was presented in December 1939 in London during the Phoney War, not at a West End theatre but in the Rudolf Steiner Hall just off Regent's Park. The Actors' Company was a shortlived 'collective', and their version was written by a then-unknown thespian, Alec Guinness and directed by the equally soon-to-be-exalted George Devine. The production was financed by a whip-round: John Lewis, eponymous founder of the retail emporium, pitched in 50 pounds and Edith Evans, not yet a dame, opened her handbag to cheerfully lose 700 pounds.

I have never seen a text, but Morley's account states that the play was narrated by 'two story tellers serving as a chorus. They were Guinness himself (who also took the role of Herbert Pocket) and his then-wife Merula Salaman (who also played Biddy). The importance of this off-Shaftesbury Avenue show is that the actress Kay Walsh went to see her friend, the stunning Martita Hunt, in the role of Miss Havisham, dragging along her reluctant husband, who had never read Dickens and whose first response to the invitation was 'Not bloody likely' (Brownlow 206). But David Lean was captivated, finding the show 'absolutely wonderful'. The intervention of hostilities postponed his desire to film the book, but in 1946 his Cineguild production became the definitive cinematic statement of the metaphorical aspirations of a post-war Britain.

\section{Part of my existence}

It took me some time to come at Great Expectations, though I had worked with Dickens's texts many times. Both The Bride's Chamber (an interpolated ghostly tale from the Dickens/Collins series of travel articles 'The Lazy Tour of Two Idle Apprentices' [1857]) and, especially, that neglected masterpiece of short fiction 'George Silverman's Explanation' (1868) had never previously been dramatised in any medium and were of such a length to make them ideal for Radio Four's 45-minute Afternoon Play slot. I am particularly fond of the five short dramas which were broadcast in the bicentennial week of February 2012 - The Special Correspondent for Posterity was lovingly stitched together from Dickens's writings throughout his life about London, but what made this project so special were the accompanying films brilliantly directed by Chris Newby, making this a unique broadcasting experiment. My screenplay of Dombey and Son fell at the final hurdle of pre-production, which is a great shame as the book has only previously been developed twice as a feature film. Interestingly, both of these fine versions - Maurice Elvey's 1919 production adapted by Eliot Stannard, patron saint of British screenwriters, and Rich Man's Folly, directed by John Cromwell in 1931 in the early days of sound - had been relocated to contemporary settings. That my rather Strindbergian domestic tragedy remains in development limbo (should that be purgatorio?) is a source of rancour and frustration. 
I had elaborate justifications for my previous Dickens adaptations: I had never seen or heard a version of Pickwick Papers that had made me laugh, and the evident fact that the young Dickens had so completely changed his mind about his middle-aged eponymous 'hero' during the course of the serialisation, transforming him from a buffoon into a saint, allowed me to, as it were, come up with the second draft he never had a chance to write. It was the part Timothy Spall was born to play, and when the BBC turned down the script they had commissioned we were able to take it to radio, though we continue to make periodic attempts to get the piece in front of a camera in one form or another.

However, I had never conceived of taking on Great Expectations, considering it pretty much perfect and remaining sceptical of previous cinematic sorties, even that of Lean so highly regarded. I am rather fond of the 12-minute 1909 distillation The Boy and the Convict included on my DVD compilation for the British Film Institute Dickens Before Sound. Perhaps my favourite adaptation is the Danish Store Forventninger, helmed by A.W. Sandberg in 1922, one of four silent versions of the works of Dickens produced by (and nearly bankrupting) the Nordisk company which is available on the website of the Danish Film Archive.

My selection as the adapter of Great Expectations was entirely due to the great director, Lucy Bailey. She had been sent three recent versions but, to her undying credit and my eternal gratitude, said she would only do it if she could work with me as writer. Lucy and I had previously collaborated on a three-part radio adaptation of George Eliot's Felix Holt, the Radical (1866) - a 'flawed' work by a great 19th-century novelist, worthy of dusting down - and on our as-yet-to-beproduced version of Thomas Hardy's Under the Greenwood Tree (1872).

Naturally, once I undertook to adapt the novel, I could not allow myself to read the plays she had turned down. But I do know that every one of them had used narration. This approach is, of course, a staple of radio drama, and was used to great effect on the stage in David Edgar's acclaimed two-part Nicholas Nickleby for the RSC back in the 1980s, where the resources of a vast company could step out of character to deliver the glories of Dickens's third-person commentary upon the characters and scenes. I confess that, for a moment, even I contemplated having three Pips: the boy on the marshes, the young would-be gentleman, and the older man breaking the fourth wall to confide to the spectators what he had come so late to learn. A short trans-hemispheric conversation with Lucy soon persuaded me this was a really terrible notion.

My 'challenge' would be to depict Pip's sentimental education, so we both understand and judge him. We have to be ahead of his own realisations before he catches up with us. This is what would create pathos and suspense, even for those audiences already aware of 'the twist in the tale': that it is not the rich, eccentric lady but the coarse convict who is the source of the wealth that allows Pip to transform himself into a gentleman, but means he can never truly be one. From the outset, there was no question for me of deploying the theatrical convention of having grown-up actors play their younger selves. Perhaps 
it was that cover of the Classics Illustrated comic, my first introduction, which convinced me that the story could not be told without the stark picture of a tiny lad confronted by a massive chained convict in a lonely churchyard. From the moment Magwitch touches the boy, Pip is marked with the taint of criminality and his life, hitherto determined as a blacksmith's apprentice, is cast into liminality - from which, it could be plausibly argued, he never quite escapes.

So, before the work began, a decision was taken which would have logistical and budgetary implications: the young Pip must be played by a young actor. This means that Estella, too, would have to be played both as a girl and as a young woman. Casting a third juvenile as Herbert Pocket was perhaps not inevitable, but it would be such a shame not to include the boxing match - a moment of light relief in the heavy atmosphere of Satis House which also thickens the plot when Pip meets the older Herbert in their metropolitan lodgings, confirming to him that it must be Miss Havisham who is his benefactress. Deciding upon three young parts meant that six young actors had to be cast as the law, not 'a ass' in this regard, requires alternation of performance and the contracting of chaperones. This inevitably put a strain on the budget, meaning we had to dispense with one adult actor, and has proven to be a stumbling block for touring the show. Nevertheless, to see young Pip working with Joe at the anvil mutating into his older self as the vision of Estella dances before him to taunt him in his role as a 'common labouring boy' more than confirmed the decision.

We had a cast of nine, plus two recipients of the West Yorkshire Playhouse Graduate Programme, which perforce imposed some interesting doubling. The actor playing Wemmick (Anthony Bunsee) had to warn Pip (Daniel Boyd) not to go home, before rushing not to snag his tights for his immediate appearance as Wopsle playing Hamlet in the next scene. Another swift backstage change came when Jaggers (Shaun Prendergast), after informing Pip of his sister's death, had to don a wig and adopt his Kentish brogue to come on as Pumblechook for her funeral. As the same actor (Rose Wardlaw) played both Missis Joe and Biddy, I had to rewrite the scene of the latter tending the former, which would have shown Biddy's kind heart and Missis Joe's parlous state after the attack. Some roles could not be doubled: Pip, whether as a child (Rhys Gannon/Sullivan Martin) or young man, cannot dilute his central presence. Neither could the towering figures of Magwitch (Ian Burfield) or Miss Havisham (Jane Asher), and Estella (Shanaya Rafaat) can only be Estella.

A more significant theatrical constraint was that we could only have one set. Clearly Great Expectations could never be 'a well-made play', following Aristotle's unities of time, place, and tone. Such proliferation of location had never troubled 19th-century theatrical professionals, as it had never bothered the Elizabethans. But staging a play with so many changes of scene does focus the minds of director and designer. However 'faithful' I wanted to be to the marvellous source text, this show could never be 'naturalistic': there would 


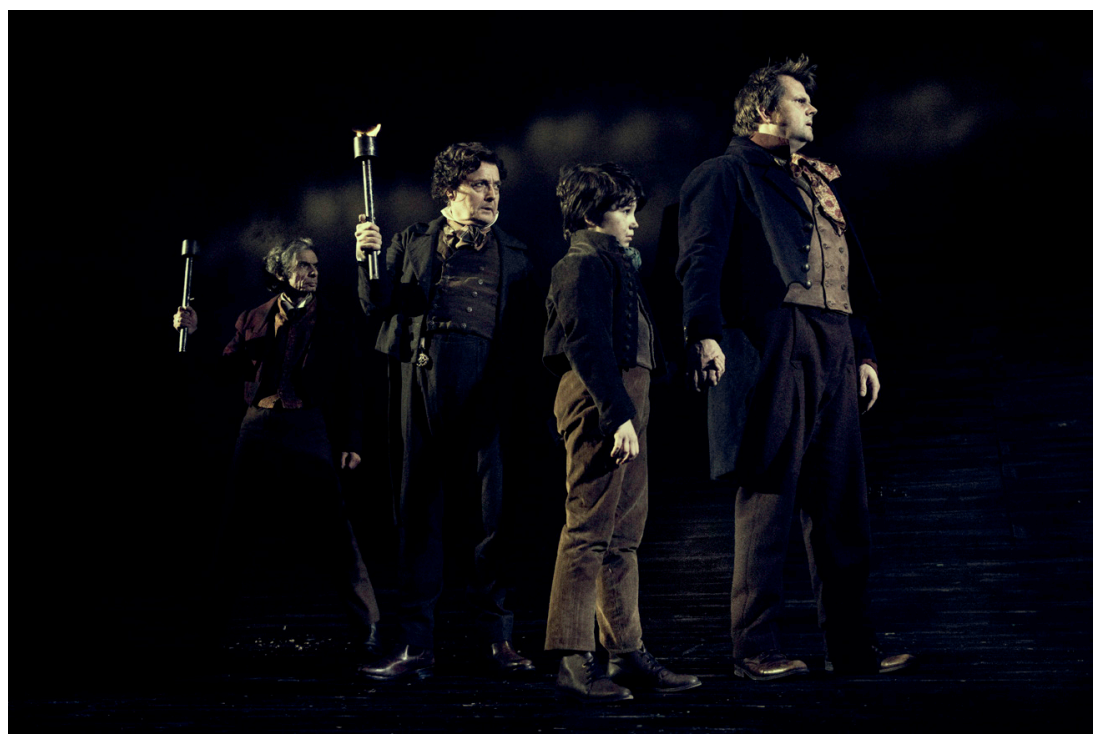

Figure 9.2: The Hunt from Eaton's production at the West Yorkshire Playhouse, 2016. Photography by Idil Sukan. Copyright Idil Sukan, reproduced with permission.

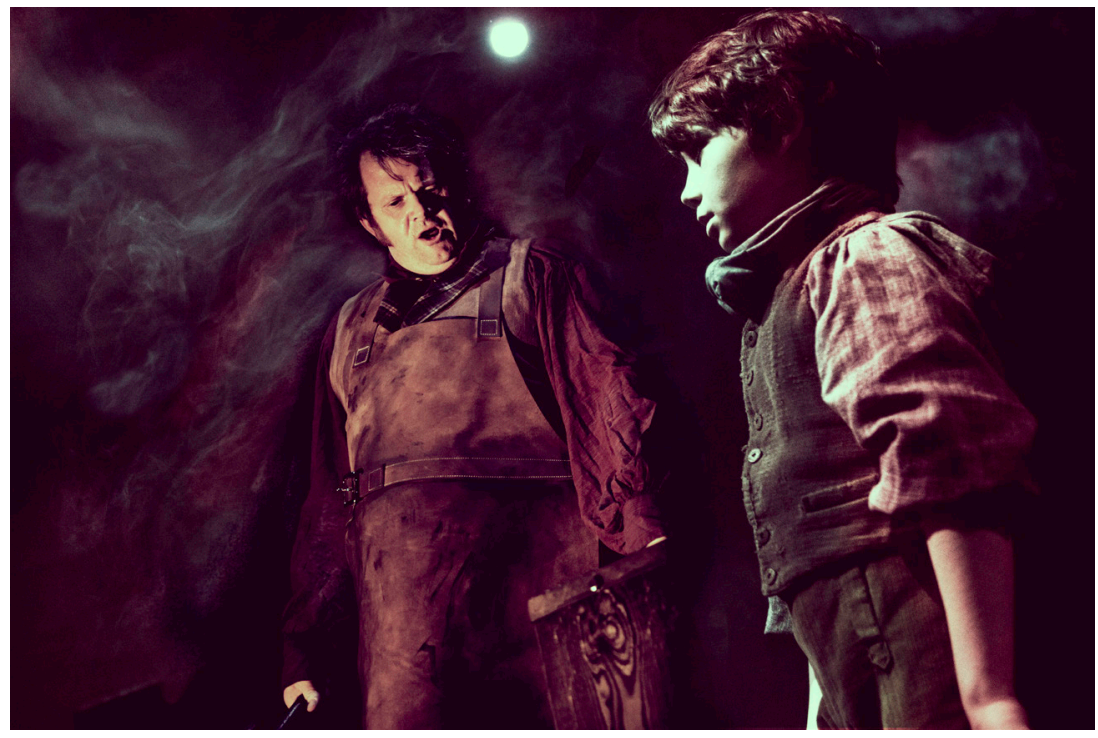

Figure 9.3: Joe's Forge from Eaton's production at the West Yorkshire Playhouse, 2016. Photography by Idil Sukan. Copyright Idil Sukan, reproduced with permission. 


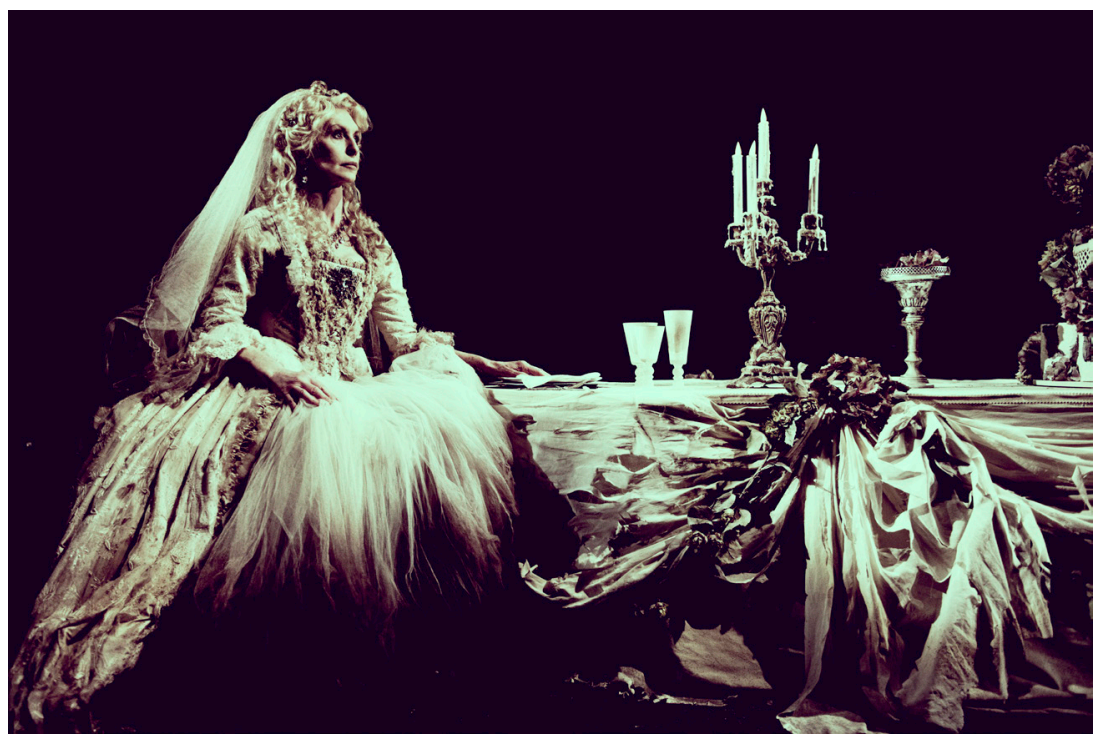

Figure 9.4: Miss Haversham's table from Eaton's production at the West Yorkshire Playhouse, 2016. Photography by Idil Sukan. Copyright Idil Sukan, reproduced with permission.

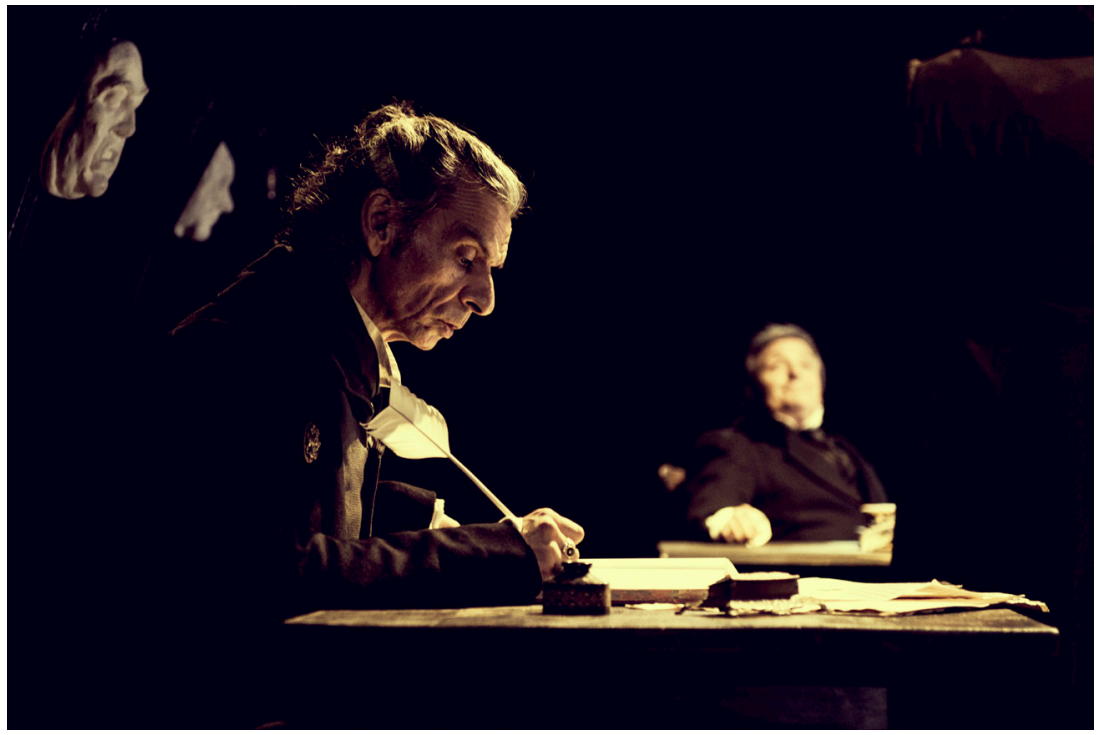

Figure 9.5: Wemmick from Eaton's production at the West Yorkshire Playhouse, 2016. Photography by Idil Sukan. Copyright Idil Sukan, reproduced with permission. 


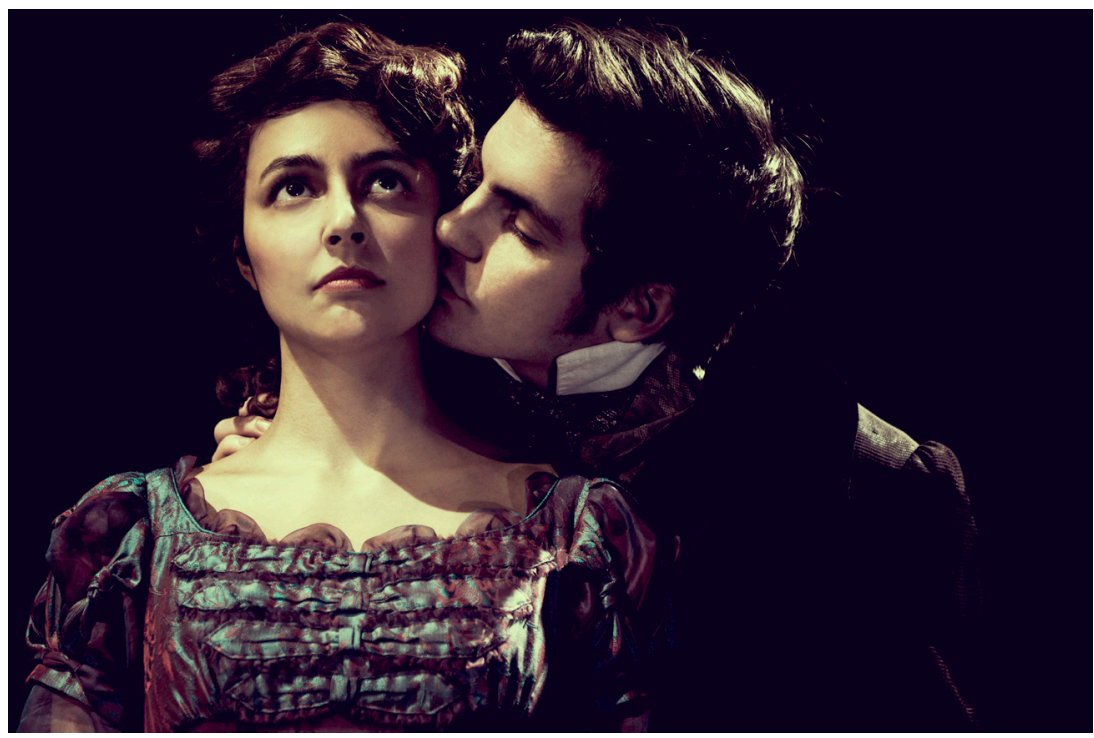

Figure 9.6: Pip and Estella from Eaton's production at the West Yorkshire Playhouse, 2016. Photography by Idil Sukan. Copyright Idil Sukan, reproduced with permission.

always have to be a certain symbolic abstraction to the design, against which our company would have to perform the drama.

It was Lucy who decided that the design would be based upon the hulk from which Magwitch escapes in the very first image of the play, providing an objective correlative to the underlying theme of that criminal taint from which Pip can never free himself. In a review for the Dickensian, Paul Graham wrote:

Set designer Mike Britton ensures that the brooding presence of the rotting, wooden prison ship is permanently moored at the centre of the action. The revolving stage presents an external view of the vessel for the scenes on the marshes and in the streets of London; whilst the claustrophobic internal structure provides the backdrop for those scenes set in forge, office and home. It enables fifty-one scene changes to be made in rapid succession with no connecting narrative voice. Criminality and its consequence - imprisonment - are ever present. Jaggers is as imprisoned by the law in his chambers as are the convicts aboard the ship; and Miss Havisham is incarcerated for life in Satis House. (162-3)

However, the limitations of having only one set - imaginative and supple as it was - meant that the climax on the Thames estuary had to be imagined as much as realised. 
So what had to go? Pip's education at the Pockets' was no great loss. But the protracted scenes of his inauguration as a member of the idle rich set, attempting to adopt the airs of a man-about-town, which Dickens evidently despised and which was effortlessly achieved cinematically through montage with voice-over in Lean's film, had to be represented somehow in a single scene which was not in the book. I chose to depict his initiation into the Finches of the Grove, as touched on in Chapter 7, a drinking club for Regency bucks presided over by the handsome and sadistic Bentley Drummle (Oliver Boot, who also neatly doubled as another cruel 'gentleman', Compeyson). If the initiation ceremony bore some resemblance to the alleged rituals of the Bullingdon Club, brought to light in the press of the time... well, that was entirely intentional.

There was no room for Walworth so, with great reluctance, there was no Aged P. Wemmick had to show the two sides of his character not topographically but linguistically: 'Speaking professionally... speaking personally.... Though we managed to keep Trabb's boy's parody of Pip's incompetent show of gentility as the tailor measures him for his London clothes, the exigencies of production meant that he could not make a reappearance on the High Street, shaming Pip with his declarations of 'Don't know ya!' The Mysterious Stranger brandishing the file in The Three Jolly Bargemen as he slips Pip the two soiled pound notes from Magwitch was, happily, included, but there was neither room nor time to reprise his expository role on the coach down to Rochester.

There were certain scenes, not usually realised in adaptations, that I was determined to keep. Wopsle playing Hamlet was obligatory for me, though it was not easy for Lucy to realise the stage and auditorium of even such a rude theatre with such a limited company. Besides, this scene is not just for comic relief but useful for the contraction of the plot, for it provides an opportunity for Orlick to point Pip out to Compeyson - which will lead the real villain of the piece, Magwitch's nemesis, to track down his old adversary.

Ah, Orlick! How to deal with this brooding, silent, slouching fellow? I have always had trouble with the curious incident of his kidnapping Pip at the sluice

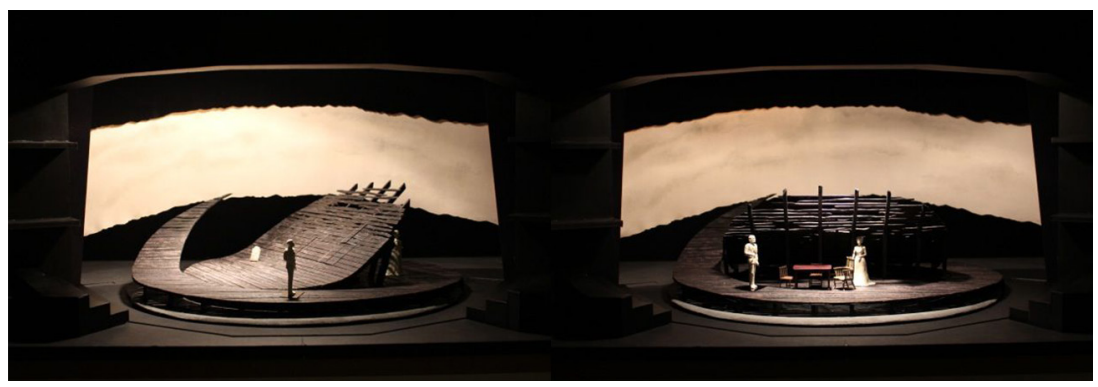

Figure 9.7: Two set models of Eaton's 2016 production, set designed by Mike Britton. Photography by Mike Britton. Copyright Mike Britton, reproduced with permission. 
house and the last-minute rescue by Herbert and Trabb's boy. It seems to occur in the wrong place, after the glorious scene of Miss Havisham's conflagration and before the preparations to smuggle 'Provis' out of the country. Many previous adaptations have, understandably, dropped this shifting character altogether, but Pip needs to know that it was Orlick who had acted out Pip's secret desire by attacking his sister. So I took the liberty to shift this revelation to the scene when Orlick is, rather unaccountably, working as the gatekeeper at Satis House, where Pip will finally confront Miss Havisham, when he will at last confess his undying love for Estella, when she will abandon them both to leave with Drummle, when Miss Havisham will beg Pip's forgiveness, when her decaying bridal dress will catch fire, and when Pip will burn his hands vainly attempting to save her.

The hardest question of all: how to end? The story is well-known of how Dickens was persuaded by his friend Bulwer-Lytton to change the original ending. ${ }^{10}$ Pip, returned from Egypt, is strolling down Piccadilly when he sees Estella in her carriage:

I was very glad afterwards to have had the interview; for, in her face and in her voice, and in her touch, she gave me the assurance, that suffering had been stronger than Miss Havisham's teaching, and had given her a heart to understand what my heart used to be. (GE 492)

But the rewrite certainly cannot be seen as a straightforward substitution of a 'happy' ending for an 'unhappy' one. The final scene is set in the ruins of Satis House - surely a more appropriate location than a fashionable London thoroughfare. But the melancholic final paragraph, evoking a distant past and an uncertain future, is anything but unambiguously hopeful:

I took her hand in mine, and as we went out of the ruined place; and as the morning mists had risen long ago when I first left the forge, so the evening mists were rising now, and in all the broad expanse of the tranquil light they showed to me, I saw no shadow of another parting from her. (358)

That last clause has been agonised over. There is certainly no definite suggestion that their lives will be united. I preserved the setting and the coincidental meeting, but I made one slight change at the very end:

\section{SCENE 50. EPILOGUE. SATIS HOUSE - DAY.}

Eleven years later... A misty, moonlit night. Older now, Pip walks into the grounds of Satis House. The building is a shell, the brickwork charred, abandoned since the fire - a ruined fairy-tale castle. A melancholy air might accompany this scene, one of Thomas Moore's Melodies might be appropriate, 'Believe me, if all those endearing young charms'. Pip starts 
as he sees a solitary figure, dressed in mourning, walking through the wreckage. Can it be?

PIP: $\quad$ Estella? Estella!

It is. Estella turns to see him - a tense unexpected yet expectant encounter. ESTELLA: I wonder you know me. I am greatly changed.

PIP: $\quad$ I would always know you. Strange... after so many years... we should meet again here - Satis House - the place of our first meeting! Do you often come back?

ESTELLA: I have never returned to this place since last I saw you.

PIP: $\quad$ The remembrance of our last meeting has always been painful to me.

ESTELLA: This ground is the only possession I have not relinquished. Everything else has gone from me, little by little. Now Satis House is to be knocked down and my wretched memories destroyed forever.

PIP: $\quad$ Poor old place!

ESTELLA: And you, Pip?

PIP: $\quad$ I've been abroad... for the last dozen or so years.

ESTELLA: Are you doing well?

PIP: I work pretty hard for a sufficient living. I suppose I do well enough.

ESTELLA: Married?

PIP: Me? No, I'm fated to be quite an old bachelor. Your husband...?

ESTELLA: Dead. A blood vessel burst in his head when he was whipping a horse. The Honourable Bentley Drummle always took pleasure in exerting mastery over weaker creatures... (changing the subject) I little thought that in taking leave of this spot I would also be taking leave of you. Let us get away from this ruin.

Estella takes Pip's hand - for a moment his heart stirs.

PIP: $\quad$ Must we part again, Estella?

ESTELLA: We are friends, Pip. (after a pause) And will continue friends... Apart.

Estella lets go of his hand and walks away. No solution. No consolation. Each condemned to a life sentence in their own individual prison. Pip is left alone.

There is no question of a life together; to me, that is inconceivable. If Pip had been cherishing one final illusion, that must now be abandoned.

Gradually, after far too short a period in the rehearsal room (the most enjoyable time for a writer, who usually has to spend far too long on his own), the 
continual chamfering of the text is fixed and final. Then suddenly, after too short a run, the show is over, the applause dies down, the motley sent back to the wardrobe, and, to adopt an image from Thackeray rather than his competitor, the box and the puppets are shut up (Vanity Fair 809). The company who have become so close now disperse, perhaps never to meet again. Yet another piece of theatre has been written on water. Yet another version of Dickens's masterpiece has become a thing of memory, while the original continues to live forever.

\section{Endnotes}

${ }^{1}$ For a fuller discussion of these illustrations, see Emily Eells, 'From Word to Image: Illustrating Great Expectations'. Nineteenth-Century Contexts, vol. 25, no. 3, 2003, pp. 219-39.

2 See Malcolm Andrews, 'Illustrations', A Companion to Charles Dickens. Edited by David Paroissien. Blackwell Publishing, 2008. 97-125.

${ }^{3}$ Leon Litvack has undertaken a reappraisal of Stone in light of his poor reputation among Dickensians; see Leon Litvack, 'Marcus Stone: A Reappraisal of Dickens's Young Illustrator', Dickens Quarterly, vol. 29, no. 3, 2012, pp. 214-50.

${ }^{4}$ See Gareth Cordery, An Edwardian's View of Dickens and His Illustrators: Harry Furniss's 'A Sketch of Boz'. ELT Press, 2005.

${ }^{5}$ See Lawrence H. Houtchens, 'Charles Dickens and International Copyright'. American Literature, vol. 13, no. 1, 1941, pp. 18-28.

${ }^{6}$ See George J. Worth, 'Great Expectations: A Drama, in Three Stages (1861)'. Dickens Quarterly, vol. 3, 1986, pp. 169-75.

7 This has been analysed by Jean Callaghan in her essay 'The (Unread) Reading Version of Great Expectations', in the Great Expectations. Norton Critical Edition, edited by Edgar Rosenberg (1999), pp. 543-55.

8 Though Gilbert's play was never printed, a transcription from the handwritten copy lodged at the Lord Chamberlain's office is available online, as are the reviews.

9 See, for example, Karl P. Wentersdorf, 'Mirror-Images in Great Expectations', Nineteenth-Century Fiction vol. 21, no. 3, 1966, pp. 203-24.

${ }^{10}$ For further discussion of the several endings, see Jerome Meckier, 'Charles Dickens's Great Expectations: A Defense of the Second Ending', Studies in the Novel, vol. 25, no. 1, 1993, pp. 28-58.

\section{Works cited}

Allingham, Philip V. 'Who Wrote the 1861 Adaptation of Great Expectations?' Victorian Web. 6 May 2003. http://www.victorianweb.org/mt/adaptations /pva334.html. Accessed 10 Jan. 2019. 
Andrews, Malcolm. 'Illustrations.' A Companion to Charles Dickens. Edited by

David Paroissien. Blackwell Publishing, 2008, pp. 97-125.

Bolton, Philip H. Dickens Dramatized. Mansell Publishing Ltd, 1987.

British Film Institute. Dickens Before Sound. 2008.

Brownlow, Kevin. David Lean: A Biography. Faber and Faber, 1997.

Callaghan, Jean. 'The (Unread) Reading Version of Great Expectations.' Great Expectations. Edited by Edgar Rosenberg. W.W. Norton and Company, Inc., 1999, pp. 543-56.

Cordery, Gareth. An Edwardian's View of Dickens and His Illustrators: Harry Furniss's 'A Sketch of Boz'. ELT Press, 2005.

Dickens, Charles. Nicholas Nickleby. Edited by Paul Schlicke. Oxford UP, 2008.

- Great Expectations. Edited by Edgar Rosenberg. W.W. Norton and Company, Inc., 1999.

- The Letters of Charles Dickens, The Pilgrim Edition, vol. 1, 1850-1852. Edited by Madeline House and Graham Storey. Clarendon Press, 1965.

Eells, Emily. 'From Word to Image: Illustrating Great Expectations'. NineteenthCentury Contexts, vol. 25, no. 3, 2003, pp. 219-39.

Forster, John. The Life of Charles Dickens. Edited by J. W. T. Ley. Cecil Palmer, 1928.

Graham, Paul. 'Great Expectations'. Dickensian, vol. 112, no. 499, 2016, pp. $162-4$.

Gilbert, W. S. Great Expectations: Drama in Three Acts and Prologue (1871). The Gilbert and Sullivan Archive. https://gsarchive.net/gilbert/plays/great_exp /index.html. Accessed 20 Nov. 2018.

. 'Dramatic Copyright'. The Times (11 Apr. 1882), p. 9.

Houtchens, Lawrence H. 'Charles Dickens and International Copyright.' American Literature, vol. 13, no. 1, 1941, pp. 18-28.

Litvack, Leon. 'Marcus Stone: A Reappraisal of Dickens's Young Illustrator.' Dickens Quarterly, vol. 29, no. 3, 2012, pp. 214-50.

Meckier, Jerome. 'Charles Dickens's Great Expectations: A Defense of the Second Ending.' Studies in the Novel, vol. 25, no. 1, 1993, pp. 28-58.

Morley, Malcolm. 'Stages of Great Expectations.' Dickensian, vol. 51, 1955, pp. 79-83.

Pemberton, Edgar. Charles Dickens and the Stage: A Record of his Connection with the Drama as Playwright, Actor and Critic. George Redway, 1888.

'Review of the First Night from The Times Friday, June 2, 1871.' The Gilbert and Sullivan Archive. https:/gsarchive.net/gilbert/plays/great_exp/times1871 .html. Accessed 20 Nov. 2018.

'Review of the 1877 Revival from The Times.' The Gilbert and Sullivan Archive https:/gsarchive.net/gilbert/plays/great_exp/times1877.html. Accessed 20 Nov. 2018.

Schelstraete, Jasper. "AA Fresh Look for Old Puppets”: Marcus Stone, Charles Dickens, and Authorship.' English, vol. 61, no. 232, 2012, pp. 51-63. 
Thackeray, William Makepeace. Vanity Fair. Edited by John Carey. Penguin, 2001.

Wentersdorf, Karl P. 'Mirror-Images in Great Expectations.' NineteenthCentury Fiction, vol. 21, no. 3, 1966, pp. 203-24.

Worth, George J. 'Great Expectations: A Drama, in Three Stages (1861).' Dickens Quarterly, vol. 3, 1986, pp. 169-75. 